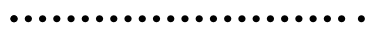

SPECT in Dementia 


\section{Advances in Biological Psychiatry}

\section{Vol. 22}

Series Editors

D. Ebert Freiburg

K.P. Ebmeier Edinburgh

W.P. Kaschka Ulm

T. Rechlin Rendsburg 


\section{……… \\ SPECT in Dementia}

Volume Editor

K.P. Ebmeier Edinburgh

29 figures, and 14 tables, 2003

KARGER 


\section{(n........................ \\ Klaus P. Ebmeier \\ Professor of Psychiatry \\ Division of Psychiatry \\ Kennedy Tower \\ Royal Edinburgh Hospital \\ Morningside Park \\ Edinburgh, EH10 5HF (UK)}

Library of Congress Cataloging-in-Publication Data

SPECT in dementia / volume editor, K.P. Ebmeier.

p. ; cm. - (Advances in biological psychiatry ; v. 22)

Includes bibliographical references and index.

ISBN 3-8055-7595-5 (hard cover : alk. paper)

1. Alzheimer's disease-Imaging. 2. Tomography, Emission. I. Ebmeier, K. P. (Klaus P.)

II. Series.

[DNLM: 1. Alzheimer Disease-radionuclide imaging. 2. Tomography,

Emission-Computed, Single-Photon-economics. 3. Tomography, Emission-Computed,

Single-Photon-methods. WT 155 S7414 2003]

RC523.S69 2003

$616.8^{\prime} 3107575-\mathrm{dc} 21$

2003054511

Drug Dosage. The authors and the publisher have exerted every effort to ensure that drug selection and dosage set forth in this text are in accord with current recommendations and practice at the time of publication. However, in view of ongoing research, changes in government regulations, and the constant flow of information relating to drug therapy and drug reactions, the reader is urged to check the package insert for each drug for any change in indications and dosage and for added warnings and precautions. This is particularly important when the recommended agent is a new and/or infrequently employed drug.

All rights reserved. No part of this publication may be translated into other languages, reproduced or utilized in any form or by any means electronic or mechanical, including photocopying, recording, microcopying, or by any information storage and retrieval system, without permission in writing from the publisher.

(C) Copyright 2003 by S. Karger AG, P.O. Box, CH-4009 Basel (Switzerland)

www.karger.com

Printed in Switzerland on acid-free paper by Reinhardt Druck, Basel

ISSN 0378-7354

ISBN 3-8055-7595-5 


\section{Contents}

1 Introduction. SPECT in Dementia - A European Initiative to Improve the Use of Single Photon Emission Computed Tomography in the Diagnosis of Dementia

Ebmeier, K.P. (Edinburgh)

4 The Clinical Use of ${ }^{99 m}$ Tc-HMPAO-SPECT in Alzheimer's Disease. A Systematic Review

Dougall, N.J. (Edinburgh); Bruggink, S. (Leiden); Ebmeier, K.P. (Edinburgh)

38 Brain Behaviour Relationships in Dementia (Neuropsychology)

Sutherland, J.K.; Dougall, N.J.; Ebmeier, K.P. (Edinburgh)

51 Assessing the Impact of Acetylcholinesterase Inhibitors with SPECT Nobili, F. (Genoa); Koulibaly, P.M. (Sophia Antipolis); Vitali, P. (Genoa);

Migneco, O. (Sophia Antipolis); Pupi, A. (Florence); Ebmeier, K.P. (Edinburgh);

Calvini, P.; Canfora, M. (Genoa); Darcourt, J. (Sophia Antipolis);

Rodriguez, G. (Genoa); Robert, P. (Sophia Antipolis)

62 Combining Images from Different Clinical Settings: Technical Issues

Koulibaly, P.M. (Sophia Antipolis); Glabus, M.F. (Shreveport, La.);

Eschner, W. (Cologne)

72 Voxel-Based Approaches in Clinical Imaging

Ebmeier, K.P. (Edinburgh); Darcourt, J. (Sophia Antipolis); Dougall, N.J. (Edinburgh);

Glabus, M.F. (Shreveport, La.); Herholz, K. (Cologne); Koulibaly, P.M.;

Migneco, O. (Sophia Antipolis); Nobili, F. (Genoa); Pupi, A. (Florence);

Robert, P. (Sophia Antipolis); Rodriguez, G. (Genoa); Scheidhauer, K. (Munich) 
86 Comparing HMPAO-SPECT and FDG-PET in Alzheimer's Disease Scheidhauer, K. (Munich); Herholz, K. (Cologne)

95 Novel SPECT Receptor Ligands for the Investigation of Dementia Pimlott, S.L.; Owens, J.; Brown, D.; Wyper, D. (Glasgow)

115 Cost Effectiveness of SPECT in Diagnosing Alzheimer's Disease Kronborg Andersen, C. (Odense); Cairns, J. (Aberdeen)

126 SPECT in Dementia: Study Implications

Prohovnik, I. (Bronx, N.Y.)

128 Subject Index 